\title{
HARVEST MANAGEMENTS AND CULTURAL PRACTICES IN SUGARCANE ${ }^{(1)}$
}

\author{
Sérgio Gustavo Quassi de Castro ${ }^{(2)}$, Henrique Coutinho Junqueira Franco ${ }^{(3)}$ \& Miguel \\ Ângelo Mutton ${ }^{(4)}$
}

\section{SUMMARY}

The presence of trash from the mechanical harvest of green cane on sugarcane plantations promotes changes in the agricultural management, for example, in the mechanical cultural practices of ratoon cane in-between the rows and nitrogen $(\mathrm{N})$ fertilization. The goal of this study was to evaluate the performance of sugarcane in different harvest systems, associated to the mechanical cultural practices in interrows and $\mathrm{N}$ rates. The study was carried out on a sugarcane plantation in Sales Oliveira, São Paulo, Brazil, with the sugarcane variety SP81-3250, on soil classified as Acrudox, in a randomized block design with split-split plots and four replications. The main treatments consisted of harvest systems (harvesting green cane or burnt cane), the secondary treatment consisted of the mechanical cultural practices in the interrows and the tertiary treatments were $\mathrm{N}$ rates $\left(0,30,60,90,120\right.$ and $\left.160 \mathrm{~kg} \mathrm{ha}^{-1}\right)$, using ammonium nitrate $(33 \% \mathrm{~N})$ as $\mathrm{N}$ source. The harvest systems did not differ in sugarcane yield (tons of cane per hectare - TCH), but in burnt cane, the pol percent and total sugar recovery (TSR) were higher. This could be explained by the higher quantity of plant impurities in the harvested raw material in the system without burning, which reduces the processing quality. Mechanical cultural practices in the interrows after harvest had no effect on cane yield and sugar quality, indicating that this operation can be omitted in areas with mechanical harvesting. The application of $\mathrm{N}$ fertilizer at rates of 88 and $144 \mathrm{~kg} \mathrm{ha}^{-1} \mathrm{~N}$, respectively, increased stalk height and TCH quadratically to the highest values for these variables. For the sugar yield per hectare (in pol \%), $\mathrm{N}$ fertilization induced a linear increase.

Index terms: nitrogen fertilization, mechanical cultural practices, green cane, Saccharum spp.

(1) Extract from a Master's thesis in Agronomy of the first author, Department of Vegetable Production, School of Agricultural and Veterinary Sciences, State University of São Paulo - Jaboticabal Campus (FCAV/UNESP). Received for publication on July 24, 2012 and approved on October 2, 2013.

(2) $\mathrm{PhD}$ in Agricultural Engineering by the Post-graduation program of the School of Agricultural Engineering, University of Campinas - FEAGRI/UNICAMP. Av. Cândido Rondon, 501, Barão Geraldo. CEP 13083-875 Campinas (SP), Brazil. E-mail: sergio.castro@bioetanol.org.br

(3) Agricultural Researcher, Brazilian Bioethanol Science and Technology Laboratory. Caixa Postal 6192. CEP 13083-875 Campinas (SP), Brazil. E-mail: henrique.franco@bioetanol.org.br

(4) Assistant Professor, Department of Vegetable Production, FCAV-UNESP. Via de Acesso Prof. Paulo Donato Castellani, s/n. CEP 14870-900 Jaboticabal (SP), Brazil. E-mail: miguelmutton@fcav.unesp.br 


\title{
RESUMO: SISTEMAS DE MANEJO DE COLHEITA E TRATOS CULTURAIS NA CULTURA DA CANA-DE-AÇÚCAR
}

\begin{abstract}
A presença da palha no campo, oriunda da colheita mecanizada sem despalha a fogo, implica em mudanças no manejo da cana-de-açúcar, como na realização do cultivo mecânico da soqueira e na fertilização nitrogenada. O objetivo deste trabalho foi avaliar o desenvolvimento da cana-de-açúcar submetida aos diferentes sistemas de colheita, associado à realização ou não do cultivo mecânico, e à aplicação de doses de nitrogênio (N). O trabalho foi desenvolvido na região de Sales Oliveira, SP, em área comercial de cana-de-açúcar, com a variedade SP81-3250 ( $2^{\circ}$ corte), em um Latossolo Vermelho acriférrico. O delineamento foi em blocos casualizados com parcelas subsubdivididas, em quatro repetições, em que os tratamentos principais eram os sistemas de colheita (cana crua ou cana queimada); os tratamentos secundários à realização ou não do cultivo mecânico; e os tratamentos terciários às doses de $N$ (0, 30, 60, 90, 120 e $\left.160 \mathrm{~kg} \mathrm{ha}^{-1}\right)$, usando como fonte o nitrato de amônio (33\% N). Os sistemas de colheita não diferiram para a produtividade da cana-de-açúcar ( $t \mathrm{ha}^{-1}$ de cana-TCH), porém a cana queimada apresentou maior teor de sacarose (Pol) e açúcar total recuperável (ATR), sendo esse fato em razão, provavelmente, do aumento das impurezas vegetais que fazem com que a qualidade tecnológica diminua. O cultivo mecânico da soqueira após a colheita da cultura não apresentou nenhum impacto na produtividade de colmos e açúcar, indicando que essa operação pode ser desconsiderada em áreas com colheita mecânica. A aplicação de fertilizante nitrogenado aumentou a altura de colmos e TCH de forma quadrática com as doses de 88 e $144 \mathrm{~kg} \mathrm{ha}^{-1}$ de $\mathrm{N}$, proporcionando os maiores valores para essas variáveis. Para a produção de açúcar por hectare (TPH), houve aumento linear em razão da adubação nitrogenada.
\end{abstract}

Termos de indexação: adubação nitrogenada, cultivo mecânico, cana crua, Saccharum spp.

\section{INTRODUCTION}

Sugarcane is the raw material for sugar and ethanol production, and a biomass source for generating electric energy (CGEE, 2009). The common practice of pre-harvest detrashing by fire, despite facilitating harvesting, loading and transportation, generates greenhouse gas emissions into the atmosphere (GHG) and degrades most of the soil organic matter and nutrients in the crop residues (Mitchell et al., 2000).

On the other hand, the crop residues (trash) left behind after mechanical harvesting of green sugarcane are composed of leaves, sheaths, plant tips, and shredded stalk pieces (Vitti et al., 2008), which, in significant quantities from 10 to $30 \mathrm{Mg} \mathrm{ha}^{-1}$ (Trivelin et al., 1996), are relevant for nutrient cycles, improvement of soil fertility and microbial activity (Macedo et al., 2008). The relationship carbon/nitrogen (C:N) in trash is approximately 100:1 (Robertson \& Thorburn, 2007), and adding this organic material to the soil may cause $\mathrm{N}$ immobilization by the microbial biomass (Vitti et al., 2008). Due to the slowness of N mineralization in the trash (Faroni et al., 2003; Vitti et al., 2011), the contribution of this process is not taken into account when managing $\mathrm{N}$ fertilizer of sugarcane ratoon (Vitti et al., 2007).

The effect of trash on sugarcane yield is complex. Several studies describe it as negative (Basanta et al., 2003), while others report a positive effect (Wood, 1991; Trivelin et al., 2002a). Relating the green cane harvesting system (without previous burning) with the soil properties and the yield potential of the sugarcane variety can help optimize the responses in sugarcane ratoon yield (Contin, 2007).

Nitrogen is an essential element for crop production and sugarcane absorption of this nutrient varies from 100 to $300 \mathrm{~kg} \mathrm{ha}^{-1}$ for a stalk production of $100 \mathrm{Mg} \mathrm{ha}^{-1}$ (Cantarella et al., 2007; Franco et al., 2008b). The amount of existing $\mathrm{N}$ in plant residues from green cane harvesting that remain on the soil after harvest can be a source of $\mathrm{N}$ ( 40 to $80 \mathrm{~kg} \mathrm{ha}^{-1}$ of $\mathrm{N}$ ) during the following ratoon crop (Fortes et al., 2011; Vitti et al., 2011; Fortes et al., 2012) and can diminish the need for mineral fertilizer application. However, $\mathrm{N}$-fertilization of the ratoon crops is imperative to satisfy the nutritional needs of $\mathrm{N}$. The recommended $\mathrm{N}$ rates vary from 60 to $120 \mathrm{~kg} \mathrm{ha}^{-1} \mathrm{~N}$ (Espironelo et al., 1996) for burnt sugarcane, and from 100 to $120 \mathrm{~kg} \mathrm{ha}^{-1}$ of $\mathrm{N}$ for green cane (Vitti \& Mazza, 2002). Research institutes have yet to establish an official recommendation for areas where sugarcane is harvested without previous burning.

Regardless of the $\mathrm{N}$-fertilizer rate applied to sugarcane plants, their use efficiency of fertilizerprovided $\mathrm{N}$ is almost always less than $50 \%$. This value is lower than in other crops (between 50 and $70 \%$ ) (Cantarella et al., 2007). Studies indicate that the use efficiency of fertilizer $\mathrm{N}$ by sugarcane can vary from 20 to $40 \%$ (Prasertsak et al., 2002; Trivelin et al., 2002b; Franco et al., 2008a; Franco et al., 2011; Vitti et al., 2011). This variation and low exploitation can be related to $\mathrm{N}$ loss in the soil-plant system, due to ammonia denitrification and volatilization (Trivelin 
et al., 2002a), leaching (Oliveira et al., 1999) and $\mathrm{N}$ gas loss by the aerial part of plants (Franco et al., 2008c).

In areas with mechanical cane harvesting, soil compression caused by agricultural machinery is inevitable, since all this equipment is extremely heavy and has a small contact surface with the soil. This small contact surface leads to a linear reduction of the soil total porosity and aeration, causing a decrease in yield and in ratoon sprouting, and tends to shorten the longevity of the sugarcane plantation (Segato et al., 2006). In this case, producers use the cultural practice of deep subsoiling in the interrow of the ratoon crop, to promote soil decompaction after mechanical harvesting operations. Studies on the effect of mechanical cultivation of ratoon crops on sugarcane yield showed a deleterious effect of this practice in areas harvested without burning (Blair, 2000; Campanhão, 2003; Castro et al., 2012), but with favorable effects in areas of burnt cane (Nunes Jr., 1998).

The objective of this study was to evaluate the response of sugarcane ratoon ( $2^{\text {nd }}$ cut) on stalk and sugar yield, related to the application of $\mathrm{N}$ rates, treated or not with mechanical cultural practices, and harvested with previous burning ("burnt cane") or without previous burning ("green cane").

\section{MATERIAL AND METHODS}

The study was carried out in the region of Sales Oliveira, São Paulo, Brazil ( $20^{\circ} 52^{\prime} 31^{\prime \prime}$ S, 47 $\left.47^{\circ} 57^{\prime} 56^{\prime \prime} \mathrm{W}\right)$, in soil classified as Acrudox, in a production environment characterized as D1 on a A to E scale, where $\mathrm{A}$ is an environment with the most favorable conditions for sugarcane development, and $\mathrm{E}$ an environment with low fertility (base saturation $<50 \%$ and low cation exchange capacity) and/or physical restrictions (low water retention), as proposed by the AmbiCana program created by the Agronomic Institute of Campinas (Instituto Agronômico de Campinas, IAC-SP). The variety SP81-3250 was assessed in the $2^{\text {nd }}$ cut (first ratoon). The maturation of this variety is medium and sprouting on trash is good (Coopersucar, 1995). In the State of São Paulo and the center-south of Brazil, SP81-3250 is grown on $13 \%$ of the entire area used for sugarcane (Chapola et al., 2010).

The experimental delimitation was performed in randomized blocks, with split-split plots subdivided in four replications: main treatments (plots) constitute the harvest systems (green cane or burnt cane); secondary treatments (split-plots) are the application or absence of mechanical cultural practices in the interrows of the crop after harvest; and tertiary treatments (split-split plots) are the $\mathrm{N}$ rates $(0,30,60$, 90,120 , and $\left.160 \mathrm{~kg} \mathrm{ha}^{-1}\right)$ manually applied near the ratoon plants (source - ammonium nitrate: $33 \% \mathrm{~N}$ ).
Each plot consisted of fifteen $500 \mathrm{~m}$-long rows of sugarcane and the split-plots of $250 \mathrm{~m}$ of the 10 central rows, and the other five were left as borders between the plots, which allowed burning of the plots and served as traffic area for the harvester. The split-splitplots were marked within the split-plots, and all consisted of five $10 \mathrm{~m}$-long central rows. These central rows were marked $20 \mathrm{~m}$ from the end of the splitplots, at a distance of $20 \mathrm{~m}$ between split-split-plots. An area of 5.7 ha was evaluated in the experiment.

Before planting, soil sampling was performed in the layers $0-0.2$ and $0.2-0.4 \mathrm{~m}$, to evaluate fertility by the method described by Raij et al. (1997). Theses samples were evaluated to characterize the soil of the experimental area. Liming was applied to raise the base saturation index (V\%) to 70. In the 0-0.2 m layer, the $\mathrm{pH}\left(\mathrm{CaCl}_{2}\right)$, SOM (soil organic matter) $\left(\mathrm{g} \mathrm{dm}^{-3}\right)$, resin $\mathrm{P}\left(\mathrm{mg} \mathrm{dm}^{-3}\right), \mathrm{S}\left(\mathrm{mg} \mathrm{dm}^{-3}\right), \mathrm{K}, \mathrm{Ca}, \mathrm{Mg}, \mathrm{Al}, \mathrm{H}+\mathrm{Al}$ (potential acidity), SB (sum of bases) and CEC (cation exchange capacity, in $\mathrm{mmol}_{\mathrm{c}} \mathrm{dm}^{-3}$ ) values and $\mathrm{V} \%$ (base saturation) were, respectively: $4.9 ; 22 ; 21 ; 26 ; 1.1$; $15 ; 5 ; 1 ; 33 ; 21.7 ; 54.7$; and 39.7. In the $0.2-0.4 \mathrm{~m}$ layer, the $\mathrm{pH}\left(\mathrm{CaCl}_{2}\right)$, $\mathrm{SOM}\left(\mathrm{g} \mathrm{dm}^{-3}\right)$, resin $\mathrm{P}\left(\mathrm{mg} \mathrm{dm}^{-3}\right)$, $\mathrm{S}\left(\mathrm{mg} \mathrm{dm}^{-3}\right) \mathrm{K}, \mathrm{Ca}, \mathrm{Mg}, \mathrm{Al}, \mathrm{H}+\mathrm{Al}, \mathrm{SB}$ and CEC $\left(\mathrm{mmol}_{\mathrm{c}} \mathrm{dm}^{-3}\right)$ values and V\% were, respectively: 5.2; $19 ; 7 ; 13 ; 0.8 ; 12 ; 3 ; 0 ; 28 ; 16.4 ; 44.4$, and 36.9 . In particle-size analysis, 719 and $742 \mathrm{~g} \mathrm{~kg}^{-1}$ clay was detected in the layers 0-0.2 and 0.2-0.4 m, respectively.

During the experimental period (June-2008 to August-2009), rainfall was measured (mm month $\left.{ }^{-1}\right)$ with a pluviometer located beside the experimental area, and a dry winter was confirmed (from June to September 2008, rainfall accumulation was only $25 \mathrm{~mm}$ ). From October 2008 to June 2009, a distribution of rainfalls with over $100 \mathrm{~mm}$ per month occurred, allowing a good crop development. During the experimental period, 1,320 $\mathrm{mm}$ of accumulated rainfall were recorded.

In March 2007, cuttings of the variety SP81-3250 from the first cut were planted, after pre-heating the buds (30 min at $52.5^{\circ} \mathrm{C}$ ) to prevent diseases. Semimechanical planting with a distribution of 15 to 20 buds per meter was used. The rows were spaced $1.50 \mathrm{~m}$ apart, with a plowing depth of $0.3 \mathrm{~m}$ and soil cover of $0.08 \mathrm{~m}$.

The plantation was fertilized with $500 \mathrm{~kg} \mathrm{ha}^{-1}$ with the 10-25-25 formula with $0.3 \% \mathrm{~B}$ and $0.5 \% \mathrm{Zn}$, resulting in the application of 50, 125, 125, 1.5, and $2.5 \mathrm{~kg} \mathrm{ha}^{-1}$ of N, $\mathrm{P}_{2} \mathrm{O}_{5}, \mathrm{~K}_{2} \mathrm{O}, \mathrm{B}$, and $\mathrm{Zn}$, respectively.

In July 2008, the 16-month-old sugarcane was harvested in a first cut and the primary treatments were applied. For this purpose, a mechanical sugarcane harvester was used. Ten days after harvest $(10 \mathrm{DAH})$, the total area was fertirrigated with vinasse at $90 \mathrm{~m}^{3} \mathrm{ha}^{-1}$, applying $150 \mathrm{~kg} \mathrm{ha}^{-1} \mathrm{~K}$.

As of the installation of the main treatments, tillering was monitored and mechanical weeding was performed. In June 2009, the number of stalks per 
split-plot was assessed in a biometric evaluation by randomly collecting 45 stalks. After cleaning and cutting off the tip of the sugar-cane plants, the stalks were electronically weighed and the height measured to calculate the yield (TCH: tons of cane per hectare). The method described by Fernandes (2003) was used to assess the technological quality, based on sugarcane Pol (Pol of cane, PC\%), as well as TPH (tons of Pol per hectare) $\left(\mathrm{Mg} \mathrm{ha}^{-1} \mathrm{Pol}\right)$ and TSR (kg TSR TC-1).were calculated.

The results were subjected to ANOVA by means of $\mathrm{F}$ testing, and the means compared by Tukey's test at $5 \%$ probability, using the statistical program AgroEstat 2011. Polynomial regression analysis was used to compare $\mathrm{N}$ rates.

\section{RESULTS AND DISCUSSION}

The harvest systems (green or burnt cane) did differ in the biometric parameters (height and TCH) (Table 1). Similar results were reported by Ceddia et al. (1999), who found an average TCH of $66.7 \mathrm{Mg} \mathrm{ha}^{-1}$ in a system of green cane, and $67.8 \mathrm{Mg} \mathrm{ha}^{-1}$ in an area of burnt cane after five consecutive crops.
Evaluating the effects of trash presence (green cane) and trash absence (burnt cane) on stalk growth in Lousiana - USA, Viator et al. (2009) found that trash promoted no increase or decrease in stalk height.

In harvest systems without previous burning, TCH increases are expected (Rossetto et al., 2010) due to nutrient recycling, in addition to a possible compensation effect on $\mathrm{N}$ supply throughout the ratoon cycle in function of the gradual mineralization of trash N (Vitti et al., 2011; Fortes et al., 2012). However, trash presence can affect sugarcane yield by hampering tillering. Sprouting can be affected in this way, because the varieties grown for commercial purposes in Brazil were genetically improved for the burnt cane harvest system, while at present, due to environmental issues, sugarcane is being harvested without previous burning, in a green cane harvest system (Tavares et al., 2010).

According to Basanta et al. (2003), leaving the trash on the ground after sugarcane harvest without previous burning protects the soil surface from direct sun radiation, diminishing water evaporation from the soil, when compared to soils with no plant cover (burnt cane). This may result in higher yields. However, these authors stated harmful effects of trash on yield (reduction), which was attributed to the fact

Table 1. Effect of the harvest system (Harv), adoption or non-adoption of mechanical cultural practices of sugarcane management (Cult) and nitrogen rates (N) on stalk height, stalk yield (TCH, tons of cane per hectare), cane Pol, TPH (tons of pol per hectare) and TSR (Total sugar recovery)

\begin{tabular}{|c|c|c|c|c|c|}
\hline Harvest system & Height & ТСH & Pol & TSR & TPH \\
\hline & $\mathrm{m}$ & $\mathrm{Mg} \mathrm{ha}^{-1}$ & $\%$ & $\mathrm{~kg} \mathrm{TCH}^{-1}$ & $\mathrm{Mg} \mathrm{ha}^{-1}$ \\
\hline Green cane & 2.5 & 115 & $14.6^{\mathrm{b}}$ & $145.8^{\mathrm{b}}$ & 16.81 \\
\hline Burnt Cane & 2.5 & 110 & $14.9^{\mathrm{a}}$ & $149.7^{\mathrm{a}}$ & 16.47 \\
\hline DMS & 0.23 & 10.6 & 0.23 & 2.4 & 1.66 \\
\hline $\mathrm{p}>\mathrm{n}$ & $0.998^{\mathrm{ns}}$ & $0.229^{\mathrm{ns}}$ & $0.019^{*}$ & $0.014^{* *}$ & $0.566^{\mathrm{ns}}$ \\
\hline \multicolumn{6}{|l|}{ Cultural practice } \\
\hline With & 2.5 & 112 & 14.8 & 148.1 & 16.59 \\
\hline Without & 2.5 & 112 & 14.8 & 147.3 & 16.69 \\
\hline DMS & 0.07 & 4.1 & 0.23 & 3.0 & 0.59 \\
\hline $\mathrm{p}>\mathrm{n}$ & $0.554^{\mathrm{ns}}$ & $0.978^{\mathrm{ns}}$ & $0.809^{\mathrm{ns}}$ & $0.537^{\mathrm{ns}}$ & $0.691^{\mathrm{ns}}$ \\
\hline \multicolumn{6}{|l|}{$\mathrm{N}$ rate $\left(\mathrm{kg} \mathrm{ha}^{-1}\right)$} \\
\hline 0 & 2.3 & 100 & 14.9 & 150.2 & 14.99 \\
\hline 30 & 2.4 & 108 & 14.8 & 149.2 & 16.14 \\
\hline 60 & 2.5 & 112 & 14.5 & 144.6 & 16.38 \\
\hline 90 & 2.5 & 117 & 14.8 & 147.7 & 17.30 \\
\hline 120 & 2.5 & 118 & 14.7 & 146.0 & 17.26 \\
\hline 160 & 2.5 & 119 & 14.9 & 148.5 & 17.77 \\
\hline $\mathrm{p}>\mathrm{n}$ & $0.0001^{* *}$ & $0.0001^{* *}$ & $0.156^{\mathrm{ns}}$ & $0.099^{\text {ns }}$ & $0.0001^{* *}$ \\
\hline Harv $\times$ Cult & $0.529^{\mathrm{ns}}$ & $0.637^{\mathrm{ns}}$ & $0.338^{\mathrm{ns}}$ & $0.537^{\mathrm{ns}}$ & $0.943^{\text {ns }}$ \\
\hline Harv $\times \mathrm{N}$ & $0.254^{\mathrm{ns}}$ & $0.406^{\mathrm{ns}}$ & $0.581^{\mathrm{ns}}$ & $0.209^{\mathrm{ns}}$ & $0.495^{\mathrm{ns}}$ \\
\hline Harv $\times \mathrm{N}$ & $0.730^{\mathrm{ns}}$ & $0.812^{\mathrm{ns}}$ & $0.066^{\mathrm{ns}}$ & $0.076^{\text {ns }}$ & $0.288^{\mathrm{ns}}$ \\
\hline Harv $\times$ Cult $\times \mathrm{N}$ & $0.607^{\mathrm{ns}}$ & $0.285^{\mathrm{ns}}$ & $0.042^{*}$ & $0.205^{\mathrm{ns}}$ & $0.089^{\mathrm{ns}}$ \\
\hline CV (\%) & 8 & 10 & 3 & 4 & 10 \\
\hline
\end{tabular}

${ }^{\text {ns }}$ non-significant, ${ }^{*}$ and ${ }^{* *}$ significant at 5 and $1 \%$, respectively. 
that trash was shred after harvest, resulting in a trash cover with a thickness of 0.15 to $0.20 \mathrm{~m}$, hampering ratoon sprouting.

When analyzing sucrose percentage (Pol) and total sugar recovery (TSR) in relation to the adopted harvest system, the values of Pol and TSR of burnt cane were higher than of green cane, in disagreement with Campanhão (2003) and Manechini (1997), who obtained higher Pol and TSR for green cane. This difference can be explained by the sugar loss through exudation after burning. However, loss in raw material quality in harvest systems without previous burning is expected, since there is a sugar loss due to cutting and transplantation of stalks in the mechanical harvest process (Ripoli, 2004). Besides, in the green cane system, the quantity of trash (plant impurities), present on the stalks after harvest is higher than in the burnt cane system, diminishing the final quality of the raw material (Pearce, 2006).

The value of TPH is calculated from the interaction between Pol and stalk yield. In this study, no difference in TPH between harvest systems was found, because there was no difference in cane yield (TCH), and the difference in Pol, although significant, was small $(2 \%)$ and did not affect TPH.

Our results showed no differences between the treatments with or without the application of cultural practices in interrows after harvest (Table 1). According to Blair (2000), these practices are used in interrows of ratoon crops for the decompaction of the subsurface soil layer, caused by machinery traffic during harvest. However, the literature results are controversial. In certain cases, these cultural practices increase yields (Souza et al., 2005) and in others, the contrary (Orlando Filho et al., 1998; Campanhão, 2003); while sometimes the yield is not affected at all, confirming the results of our study (Ide et al., 1994; Paulino et al., 2004; Camilotti et al., 2005).

In areas of sugarcane production on tropical soils, $\mathrm{N}$ fertilization is essential due to the low $\mathrm{N}$ availability for the crop. This was confirmed in this study, because the tested N rates improved crop development (Table 1), both in terms of biometric parameters and sugar yield per hectare (TPH). For the parameter plant height, a quadratic response was confirmed (Figure 1) at a rate of $88 \mathrm{~kg} \mathrm{ha}^{-1} \mathrm{~N}$, resulting in the tallest plants $(2.50 \mathrm{~m})$. This proves that within only one growing season, $\mathrm{N}$ in trash becomes insignificant for sugarcane nutrition compared to the fertilizer available after its application (Vitti et al., 2011).

In a wide bibliographic revision of 37 studies analyzing the response of sugarcane ratoon harvested without previous burning to the application of different $\mathrm{N}$ rates, Quassi de Castro \& Otto (2013) confirmed that only six studies found no response to $\mathrm{N}$ fertilization, 21 described an average response (increase of yield up to $25 \%$ ) and 10 reported a high response to $\mathrm{N}$ fertilization in ratoons (increase of yield higher than $25 \%$ ). This great variation in sugarcane response to $\mathrm{N}$-fertilizer indicates that there are various factors (climate, soil texture, handling techniques, cutting period, etc.) affecting the sugarcane response to N. This highlights the importance of studies that evaluate the sugarcane response curve to $\mathrm{N}$, considering the great variability of fertility in the main soil types found in Brazil, the different sugarcane varieties grown for commercial purposes, the different harvest periods throughout the crop and, particularly, the lack of diagnostic methods for recommendation of $\mathrm{N}$ application to sugarcane.

According to Trivelin (2000), $\mathrm{N}$ is one of the most restrictive factors in sugarcane crop development. The crop response to $\mathrm{N}$ fertilization had already been demonstrated by other studies in Brazil (Trivelin et al., 2002a,b; Franco et al., 2008b; Fortes et al., 2011, 2012 , 2013). However, the authors' opinions differ with regard to the relation between the maximum yield and required N rate. Korndörfer et al. (2002) obtained mean increases of $10 \mathrm{TCH}$ with an application of $60 \mathrm{~kg} \mathrm{ha}^{-1} \mathrm{~N}$. Fortes et al. (2011) obtained the highest yield with $100 \mathrm{~kg} \mathrm{ha}^{-1} \mathrm{~N}$, while the average yield of three ratoon crops increased most with $120 \mathrm{~kg} \mathrm{ha}^{-1} \mathrm{~N}$ (Fortes et al., 2013). In this study, the $\mathrm{N}$ rates with a quadratic effect on $\mathrm{TCH}$ with maximum yield (119 $\left.\mathrm{Mg} \mathrm{ha}^{-1}\right)$ were obtained with $144 \mathrm{~kg} \mathrm{ha}^{-1} \mathrm{~N}$ (Figure 2). A similar behavior was found by Quassi de Castro \& Otto (2013), after obtaining a response

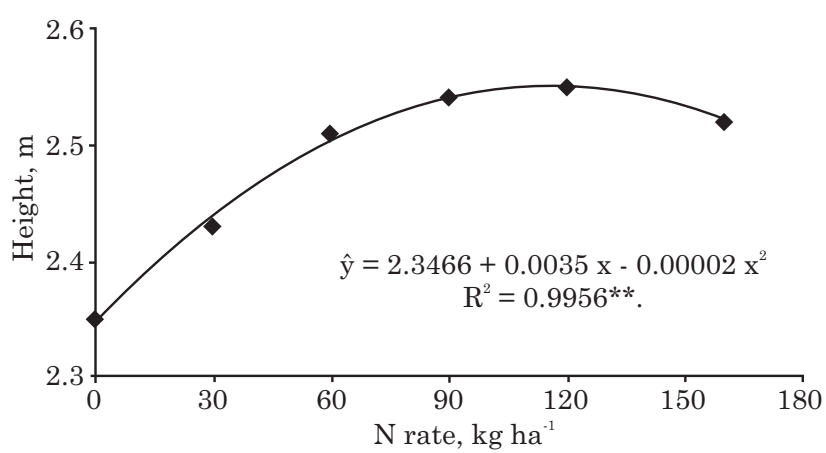

Figure 1. Effect of $\mathrm{N}$-fertilizer rates on stalk height in sugarcane.

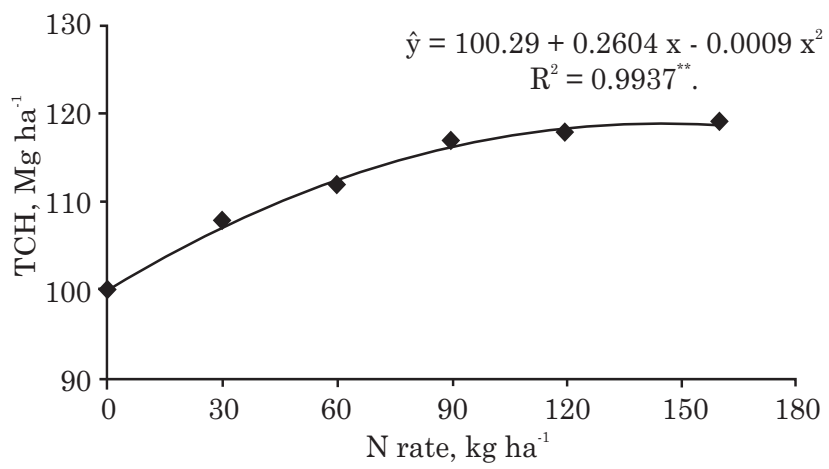

Figure 2. Effect of $\mathrm{N}$-fertilizer rates on stalk yield (TCH) in sugarcane. 
curve of the relationship between yield (TCH) and $\mathrm{N}$ rate applied in 37 experiments. In the study of these authors, there was a quadratic response to $\mathrm{N}$ fertilization, with maximum yields $\left(95.36 \mathrm{Mg} \mathrm{ha}^{-1}\right)$ at $136 \mathrm{~kg} \mathrm{ha}^{-1} \mathrm{~N}$ rates.

Cultural practices throughout the sugarcane cycle can alter the technological quality of raw material, mainly the sugar content in stalks. Studies show that $\mathrm{N}$ fertilization can diminish the percentage of sucrose (Pol), which is attributed to the effect of dilution due to the higher water content in the plant, and higher consumption due to plant development caused by $\mathrm{N}$ fertilization (Wiedenfeld, 1998). In general, for each percentage unit increase of $\mathrm{TCH}$ due to $\mathrm{N}$, the sugar percentage in stalks decreases by $0.01 \%$ (Korndörfer \& Martins, 1992). Other authors (Espironelo et al., 1977; Silveira et al., 1981) also found harmful effects of $\mathrm{N}$ fertilization, especially at high $\mathrm{N}$ rates (above $120 \mathrm{~kg} \mathrm{ha}^{-1} \mathrm{~N}$ ), on sucrose (Pol) accumulation in sugarcane. However, in this study, there were no differences in $\mathrm{Pol}$ cane content in function of $\mathrm{N}$ fertilization. Nevertheless, the increasing $\mathrm{N}$ rates had a linear effect on TPH (Figure 3). These results confirmed the findings of Orlando Filho et al. (1994), Korndörfer et al. (1997, 2002), Trivelin et al. (2002b), Franco et al. (2010) and Fortes et al. (2013), that N fertilization also increased TPH, as a result of the yield increased by $\mathrm{N}$ fertilization.

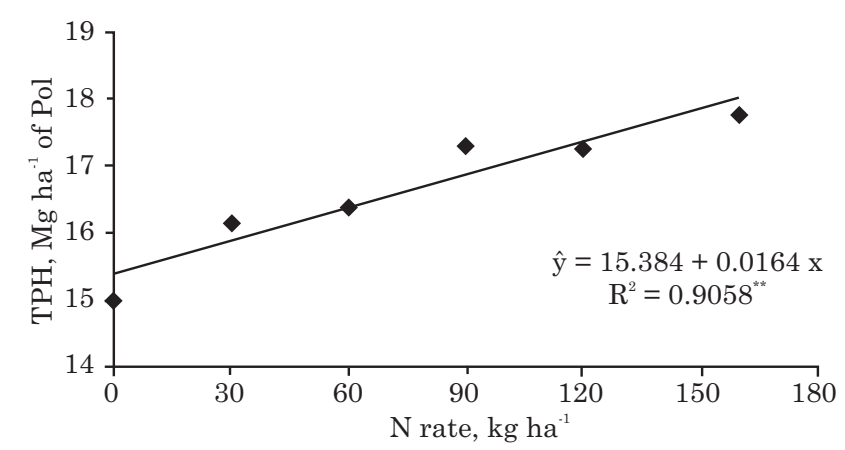

Figure 3. Effect of $\mathrm{N}$-fertilizer rates on sugar yield (TPH) in sugarcane.

\section{CONCLUSIONS}

1. Adopting different harvesting systems in sugarcane does not lead to differences in stalk yield (TCH) and sugar yield (TPH). Pol percent and TSR values are higher in the burnt sugarcane systems.

2. The mechanical cultural practices of ratoon had no effects on stalk yield, sugar, or the technological quality of sugarcane, indicating the importance of discussing the need of this procedure after harvesting.

3. The application of $\mathrm{N}$-fertilizer increased stalk height and TCH at doses of 88 and $144 \mathrm{~kg} \mathrm{ha}^{-1} \mathrm{~N}$, respectively, to the highest values for these variables.

\section{LITERATURE CITED}

BASANTA, M.V.; DOURADO NETO, D.; REICHARDT, K.; BACCHI, O.O.S.; OLIVEIRA, J.C.M.; TRIVELIN, P.C.O.; TIMM, L.C.; TOMINAGA, T.T.; CORRECHEL, V.; CÁSSARO, F.A.M.; PIRES, L.F. \& MACEDO, J.R. Management effects on nitrogen recovery um a sugarcane crop grown in Brazil. Geoderma, 116:235-248, 2003.

BLAIR, N. Impact of cultivation and sugarcane green trash management on carbon fractions and aggregate stability for a Chromic Luvisol in Queensland, Australia. Soil Till. Res., 55:183-191, 2000.

CAMPANHÃO, J.M. Manejo da soqueira de cana-de-açúcar submetida à queima acidental da palhada remanescente da colheita mecanizada. Jaboticabal, Universidade Estadual Paulista, 2003. 75p. (Dissertação de Mestrado)

CAMILOTTI, F.; ANDRIOLI, I.; DIAS, F.L.F.; CASAGRANDE, A.A.; SILVA, A.R.; MUTTON, M.A. \& CENTURION, J.F. Efeito prolongado de sistemas de preparo do solo com e sem cultivo de soqueira de cana crua em algumas propriedades físicas do solo. Eng. Agríc., 25:189-198, 2005.

CANTARELlA, H.; TRIVELIN, P.C.O. \& VITTI, A.C. Nitrogênio e enxofre na cultura da cana-de-açúcar. In: YAMADA, T.; ABDALLA, S.R.S. \& VITTI, G.C., eds. Nitrogênio e enxofre na agricultura brasileira. Piracicaba, IPNI Brasil, 2007. p.407-464.

CASTRO, S.G.Q.; MUTTON, M.A.; BARBOSA, J.C. \& QUASSI DE CASTRO, S.A. Aplicação diferenciada de nitrogênio em soqueira de cana-de-açúcar. In: REUNIÃO BRASILEIRA DE FERTILIDADE DO SOLO E NUTRIÇÃO DE PLANTAS, 30., Maceió, 2012. Anais... Maceió, SBCS/UFAL, 2012.

CEDDIA, M.B.; ANJOS, L.H.C.; LIMA, E.; RAVELLI NETO, A. \& SILVA, L.A. Sistemas de colheita da cana-de-açúcar e alterações nas propriedades físicas de um solo Podzólico Amarelo no Estado do Espírito Santo. Pesq. Agropec. Bras., 34:1467-1473, 1999.

CENTRO DE GESTÃo E ESTUdos ESTRATÉGiCOS CGEE. Bioetanol combustível: Uma oportunidade para o Brasil. Brasília, 2009. 536p.

CHAPOLA, R.G.; HOFFMANN, H.P.; BASSINELLO, A.I.; FERNANDES JUNIOR, A.R.; BRUGNARO, C.; ROSA, J.R.B.F.; VIEIRA, M.A.S. \& SCHIAVINATO, S.R. Censo varietal de cana-de-açúcar de São Paulo, Mato Grosso e Mato Grosso do Sul. STAB, 28:34-37, 2010.

CONTIN, T.L.M. Ureia tratada com inibidor da urease NBPT na adubação da cana-de-açúcar colhida sem despalha a fogo. Campinas, Instituto Agronômico de Campinas, 2007. 72p. (Dissertação de Mestrado)

COOPERSUCAR. Quinta geração de variedades de cana-deaçúcar. Piracicaba, Coopersucar, 1995. (Boletim Técnico)

ESPIRONELLO, A; RAIJ, B. Van, PENATTI, C.P.; CANTARELLA, H.; MORELLI, J.L.; ORLANDO FILHO, J.; LANDELL, M.G.A.; ROSSETTO, R. Cana-de-açúcar. In: RAIJ, B. van; CANTARELLA, H.; QUAGGIO, J.A.; FURLAN I, A.M.C., eds. Recomendações de adubação e calagem para o estado de São Paulo. Boletim 100, Fundação IAC, Campinas, p. 237-239, 1996. 
ESPIRONELO, A.; OLIVEIRA, H. \& NAGAI, V. Efeito da adubação nitrogenada em cana-de-açúcar (cana-planta) em anos consecutivos de plantio. I. Resultados de 1974/75 e 1975/76. R. Bras. Ci. Solo, 1:76-81, 1977.

FARONI, C.E.; VITTI, A.C.; GAVA, G.J.C.; MANZONI, C.S.; PENATTI, C.P. \& TRIVELIN, P.C.O. Degradação da palha $(15 \mathrm{~N})$ de cana-de-açúcar em dois anos consecutivos. In: CONGRESSO BRASILEIRO DE CIÊNCIA DO SOLO, 29., Ribeirão Preto, 2003. Anais... Ribeirão Preto, UNESP/ SBCS, 2003. CD ROM.

FERNANDES, A.C. Cálculos na agroindústria de cana-deaçúcar. 2.ed. Piracicaba, STAB, 2003. 240p.

FORTES, C.; TRIVELIN, P.C.O.; VITTI, A.C.; FERREIRA, D.A.; FRANCO, H.C.J. \& OTTO, R. Recovery of nitrogen $\left({ }^{15} \mathrm{~N}\right)$ by sugarcane from previous crop residues and urea fertilization under a minimum tillage system. Sugar Technol., 13:42-46, 2011.

FORTES, C.; TRIVELIN, P.C.O. \& VITTI, A.C. Long-term decomposition of sugarcane harvest residues in Sao Paulo State Brazil. Biomass Bioener., 42:189-198, 2012.

FORTES, C.; TRIVELIN, P.C.O.; VITTI, A.C.; OTTO, R.; FRANCO, H.C.J. \& FARONI, C.E. Nitrogen responses in the agro- industrial production of sugarcane under reduced tillage in southeastern Brazil. Pesq. Agropec. Bras., 48:88-96, 2013.

FRANCO, H.C.J.; OTTO, R.; FARONI, C.E.; VITTI, A.C.; ALMEIDA DE OLIVEIRA, E.C. \& TRIVELIN, P.C.O. Nitrogen in sugarcane derived from fertilizer under Brazilian field conditions. Field Crop Res., 121:29-41, 2011.

FRANCO, H.C.J.; TRIVELIN, P.C.O.; FARONI, C.E.; VITTI, A.C. \& OTTO, R. Aproveitamento pela cana-de-açúcar da adubação nitrogenada de plantio. R. Bras. Ci. Solo, 32:2763-2770, 2008a

FRANCO, H.C.J.; CANTARELLA, H.; TRIVELIN, P.C.O.; VITTI, A.C.; OTTO, R.; FARONI, C.E.; SARTORI, R.H. \& TRIVELIN, M.O. Acúmulo de nutrientes pela cana planta. STAB, 26:47-51, 2008b.

FRANCO, H.C.J.; DAMIN, V.; FRANCO, A.; MORAES, M.F. \& TRIVELIN, P.C.O. Perda de nitrogênio pela Brachiaria decumbens após a antese: Relação com a umidade do solo. Ci. Rural, 38:96-102, 2008c.

FRANCO, H.C.J.; TRIVELIN, P.C.O.; FARONI, C.E.; VITTI, A.C. \& OTTO, R. Stalk yield and technological attributes of planted cane as related to nitrogen fertilization. Sci. Agric., 67:579-590, 2010.

IDE, B.Y.; OLIVEIRA, M.A. \& LOPES, J.R. Cultivo de soqueira em cana-de-açúcar. Piracicaba, Centro de Tecnologia Coopersucar, 1994. p.15-21. (Boletim Técnico, 26)

KORNDÖRFER, G.H.; COLOMBO, C.A.; CHIMELLO, M.A. \& LEONI, P.L.C. Desempenho de variedades de cana-deaçúcar cultivadas com e sem nitrogênio. In: CONGRESSO NACIONAL DA SOCIEDADE DOS TÉCNICOS AÇUCAREIROS E ALCOOLEIROS DO BRASIL, 8., Recife, 2002. Anais... Recife, STAB, 2002. p.234-238.

KORNDÖRFER, G.H. \& MARTINS, M. Importância da adubação na qualidade da cana-de-açúcar. STAB, 10:2631, 1992 .
KORNDÖRFER, G.H.; VALLE, M.R.; MARTINS, M. \& TRIVELIN, P.C.O. Aproveitamento do nitrogênio da ureia pela cana-planta. R. Bras. Ci. Solo, 21:23-26, 1997.

MACEDO, I.C.; SEABRA, J.E.A. \& SILVA, J.E.A.R. Greenhouse gas emissions in the production and use of ethanol from sugarcane in Brazil: The 2005/2006 averages and a prediction for 2020. Biomass Bioener., 32:582-595, 2008.

MANECHINI, C. Manejo da cana crua. In: SEMINÁRIO COPERSUCAR DE TECNOLOGIA AGRONÔMICA, 7., Piracicaba, 1997. Anais... Piracicaba, Coopersucar, 1997. p.309-327.

MITCHELL, R.D.J.; THORBURN, P.J. \& LARSEN, P. Quantifying the loss of nutrients from the immediate area when sugarcane residues are burnt. Proc. Aust. Soc. Sugar Cane Tecnol., 22:206-211, 2000.

NUNES JR., D. In: WORKSHOP "CANA CRUA" - UNESP, 1998. Jaboticabal. Palestra... Jaboticabal, UNESP, 1998.

OLIVEIRA, M.W.; TRIVELIN, P.C.O.; GAVA, G.J.C. \& VITTI, A.C. Lixiviação de nitrogênio em solo cultivado com canade-açúcar: experimento em lisímetro. STAB, 8:28-31, 1999.

ORLANDO FILHO, J.; CARMELLO, Q.A.C.; PEXE, C.A. \& GLÓRIA, A.M. Adubação de soqueiras de cana-de-açúcar sob dois tipos de despalha: Cana crua $\mathrm{x}$ cana queimada. STAB, 12:7-11, 1994.

ORLANDO FILHO, J.; ROSSETTO, R.; MURAOK, T. \& ZOTELLI, H.B. Efeitos do sistema de despalha (cana crua x cana queimada) sobre algumas propriedades do solo. STAB, 16:30-35, 1998 .

QUASSI DE CASTRO, S.A \& OTTO, R. Resposta da cana crua à adubação nitrogenada. In: SIMPÓSIO DE TECNOLOGIA DE PRODUÇÃO DE CANA-DEAÇÚCAR, 6., Piracicaba, 2013, Anais... Piracicaba, 2013. p.169-177.

PAULINO, A.F.; MEDINA, C.C.; AZEVEDO, M.C.B.; SILVEIRA, K.R.P.; TREVISAN, A.A. \& MURATA, I.M. Escarificação de um Latossolo Vermelho na pós colheita de soqueira de cana-de-açúcar. R. Bras. Ci. Solo, 28:911917, 2004.

PEARCE, J. Evolução constante. Cult. Maq., 51:12-13, 2006.

PRASERTSAK, P.; FRENEY, J.R.; DENMEAD, O.T.; SAFFIGNA, P.G.; PROVE, B.G. \& REGHENZANI, J.R. Effects of fertilizer placement on nitrogen loss from sugarcane in tropical Queensland. Nutr. Cycl. Agroecosyst., 62:229-239, 2002.

RAIJ, B.van; CANTARELLA, H.; QUAGGIO, J.A. \& FURLANI, A.M.C. Recomendações de adubação e calagem para o Estado de São Paulo. 2.ed. Campinas, Instituto Agronômico/Fundação IAC, 1997. 285p.

RIPOLI, T.C.C. \& RIPOLI, M.L.C. Biomassa de cana-de-açúcar: Colheita, energia e ambiente. Piracicaba, T.C.C. Ripoli, 2004. 302p.

ROBERTSON, F.A. \& THORBURN, P.J. Decomposition of sugarcane harvest residue in different climatic zones. Aust. J. Soil Res., 45:1-11, 2007. 
ROSSETTO, R.; DIAS, F.L.F.; LANDELL, M.G.A.; CANTARELLA, H.; TAVARES, S.; VITTI, A.C. \& PERECIN, D. $\mathrm{N}$ and $\mathrm{K}$ fertilization of sugarcane rations harvested without burning. Proc. Inter. Soc. Sugar Cane Technol., 27:1-8, 2010.

SEGATO, S.V.; PINTO, A.S.; JENDIROBA, E. \& NÓBREGA, J.C.M. Atualização em produção da cana-de-açúcar. 2.ed. Piracicaba, PROL, 2006. 415p.

SILVEIRA, J.A.G. \& CROCOMO, O.J. Biochemical and physiological aspects of sugarcane (Saccharum spp.). I. Effects of $\mathrm{NO}_{3}{ }^{-}$-nitrogen concentration on the metabolism or sugar and nitrogen. Energia Nuclear Agric., 3:19-33, 1981.

SOUZA, Z.M.; PAIXÃO, A.C.S.; PRADO, R.M.; CESARIN, L.G. \& SOUZA, S.R. Manejo de palhada de cana colhida sem queima, produtividade do canavial e qualidade do caldo. Ci. Rural, 35:1062-1068, 2005.

TAVARES, O.C.H.; LIMA, E. \& ZONTA, E. Crescimento e produtividade da cana planta cultivada em diferentes sistemas de preparo do solo e de colheita. Acta Sci. Agron., 32:61-68, 2010.

TRIVELIN, P.C.O. Utilização do nitrogênio pela cana-deaçúcar: três casos estudados com o uso do traçador $15 \mathrm{~N}$. Piracicaba, Centro de Energia Nuclear na Agricultura, Universidade de São Paulo, 2000. 143p. (Tese de LivreDocência)

TRIVELIN, P.C.O.; OLIVEIRA, M.W.; VITTI, A.C.; GAVA, G.J.C. \& BENDASSOLLI, J.A. Perdas de nitrogênio da uréia no sistema solo-planta em dois ciclos de cana-deaçúcar. Pesq. Agropec. Bras., 37:193-201, 2002a.

TRIVELIN, P.C.O.; VICTORIA, R.L. \& RODRIGUES, J.C. Aproveitamento por soqueira de cana-de-açúcar de final de safra do nitrogênio da aquamônia- ${ }^{15} \mathrm{~N}$ e aplicado ao solo em complemento à vinhaça. Pesq. Agropec. Bras., 30:1375-1385, 1996.
TRIVELIN, P.C.O.; VITTI, A.C.; OLIVEIRA, M.W.; GAVA, G.J.C.; \& SARRIÉS, G.A. Utilização de nitrogênio e produtividade da cana-de-açúcar (cana-planta) em solo arenoso e com incorporação de resíduos da cultura. R. Bras. Ci. Solo, 26:637-646, 2002b.

VIATOR, R.P.; JOHNSON, R.M.; BOYKIN, D.L. \& RICHARD JR., E.P. Sugarcane postharvest residue management in a temperate climate. Crop Sci., 49:1-6, 2009.

VITTI, A.C.; FRANCO, H.C.J.; TRIVELIN, P.C.O.; FERREIRA, D.A.; OTTO, R.; FORTES, C. \& FARONI, C.E. Nitrogênio proveniente da adubação nitrogenada e de resíduos culturais na nutrição da cana-planta. Pesq. Agropec. Bras., 46:287-293, 2011.

VITTI, G.C. \& MAZZA, J.A. Planejamento, estratégias de manejo e nutrição da cultura da cana-de-açúcar. Piracicaba, Potafós, 2002. 16p. (Informações Agronômicas, 97)

VITTI, A.C.; TRIVELIN, P.C.O.; GAVA, G.J.C.; FRANCO, H.C.J.; BOLOGNA, I.R. \& FARONI, C.E. Produtividade da cana-de-açúcar relacionada à localização de adubos nitrogenados aplicados sobre os resíduos culturais em canavial sem queima. R. Bras. Ci. Solo, 31:491-498, 2007.

VITTI, A.C.; TRIVELIN, P.C.O.; FRANCO, H.C.J.; OTTO, R.; FARONI, C.E. \& CANTARELLA, H. Recuperação pela cana-de-açúcar do $\mathrm{N}$ dos resíduos culturais e da adubação nitrogenada de plantio. In: CONGRESSO NACIONAL DA STAB, 9., 2008, Maceió. Anais... Maceió, STAB, 2008. CD-ROM

WIEDENFELD, R.P. Previous crop effects on sugarcane responses to nitrogen fertilization. Agron. J., 90:161-165, 1998.

WOOD, A.W. Management of crop residues following green harvesting of sugarcane in north Queensland. Soil Till. Res., 20:69-85, 1991. 